\title{
GI9. ASSESSMENT OF PARAMETERS FOR LOT RELEASE OF TETANUS ANTITOXIN FOR HUMAN USE THROUGH POTENCY ASSAYS BY TOBITEST.
}

Deivid Wanderson Couto dos Anjos ${ }^{1}$; Kelly Oliveira Santos ${ }^{1}$; Andrea Pereira Larangeira $^{1}$; Wlamir Correa de Moura ${ }^{2}$; Isabella Fernandes Delgado ${ }^{1}$.

${ }^{1}$ INCQS / Fiocruz;

${ }^{2} \mathrm{BraCVAM} / \mathrm{INCQS} /$ Fiocruz.

INTRODUCTION The incidence of tetanus is still a public health problem in Brazil. The biological product adopted by National Immunisations Programme (NIP) for prophylactic and therapeutic purposes is the Tetanus Antitoxin for Human Use (TAHU). The National Institute for Quality Control in Health (INCQS) is the Brazilian laboratory responsible for evaluating the quality of TAHU lots. Potency assays for TAHU employ a large number of mice by tetanus toxin neutralisation testing (TNT). The Toxin Binding Inhibition (ToBI) test is a promising alternative to replace the use of animals in testing.

OBJECTIVE The aim of this study is to verify the adequacy of current minimum potency requirement $(1000 \mathrm{IU} / \mathrm{ml})$ for routine lot release of TAHU using ToBI test as an alternative to TNT in mice.

METHODOLOGY Twenty-five samples of commercial TAHU batches received in INCQS from 2010 to 2013 were randomly chosen from Brazilian producers. Samples were pre-diluted 1:250 (estimating higher potencies); 1:500 (standard assay procedure); and 1:1000 (estimating lower titres). TNT in mice: the assays were performed as described in TAHU monograph from The Brazilian Pharmacopoeia, using reference preparations calibrated against the lnternational Standards. The potency requirement for TAHU is not less than $1000 \mathrm{IU} / \mathrm{ml}$. ToBI test: $100 \mu \mathrm{l}$ of twofold dilutions of both reference and test sera were prepared in PBS and mixed with $100 \mu$ of tetanus toxin at $0.25 \mathrm{Lf} / \mathrm{ml}$ in blocked pre-incubation microplates. After one hour at $37^{\circ} \mathrm{C}$ in humid atmosphere followed by overnight incubation at $2-8^{\circ} \mathrm{C}$, the non-neutralised toxin was caught by transferring $100 \mu \mathrm{l}$ of the serum-toxin mixtures to immunoassay plates coated with tetanus antibodies. When the complex [Antibody-Toxin-Tetanus antitoxin conjugated to peroxidase] reacted with 3,3,5,5'-tetramethylbenzidine substrate, the 
plates was read at 450nm after use of $\mathrm{H} 2 \mathrm{SO} 4$ solution. Positive and negative controls should not exceed measures of absorbance of $0.01-0.1$ and $0.5-1.3$, respectively. The in vitro assays dose response curves should present significant regression $(\mathrm{p}<0.05)$ and no deviations of parallelism and linearity $(p>0.05)$.

RESULTS Potency estimates through ToBI using a calibration curve by a 4-parameter logistic fit instead of $\mathrm{OD}_{50}$ methods obtained better correlation to TNT. The Linear Regression Equation $(y=a x+b$, where $x=$ potency value by TNT; $y=$ potency value by ToBI) described the tendency of correlation very well. Then, it was possible to determine a novel minimal acceptable potency around $1600 \mathrm{IU} / \mathrm{ml}$ with specificity $100 \%$ to discriminate subpotent and potent batches using ToBI test.

CONCLUSION The threshold of $1000 \mathrm{IU} / \mathrm{ml}$ has not presented adequate specificity for routine lot release of TAHU through ToBI test. Thus, the establishment of a novel minimum potency requirement for ToBI test is suitable. Therefore, potency results obtained by ToBI test showed very good correlation with TNT, emphasising the replacement of expensive TNT in mice is feasible.

KEYWORDS tetanus hyperimmune serum, potency test, lot release, alternative method. 